\title{
The Influence of $\mathrm{Al}_{2} \mathrm{O}_{3}$ Powder Morphology on the Properties of $\mathrm{Cu}-\mathrm{Al}_{2} \mathrm{O}_{3}$ Composites Designed for Functionally Graded Materials (FGM)
}

\author{
Agata Strojny-Nędza, Katarzyna Pietrzak, and Witold Węglewski
}

\author{
(Submitted November 3, 2015; in revised form May 20, 2016; published online July 11, 2016)
}

\begin{abstract}
In order to meet the requirements of an increased efficiency applying to modern devices and in more general terms science and technology, it is necessary to develop new materials. Combining various types of materials (such as metals and ceramics) and developing composite materials seem to be suitable solutions. One of the most interesting materials includes $\mathrm{Cu}-\mathrm{Al}_{2} \mathrm{O}_{3}$ composite and gradient materials (FGMs). Due to their potential properties, copper-alumina composites could be used in aerospace industry as rocket thrusters and components in aircraft engines. The main challenge posed by copper matrix composites reinforced by aluminum oxide particles is obtaining the uniform structure with no residual porosity (existing within the area of the ceramic phase). In the present paper, $\mathrm{Cu}-\mathrm{Al}_{2} \mathrm{O}_{3}$ composites (also in a gradient form) with 1, 3, and $5 \mathrm{vol} . \%$ of aluminum oxide were fabricated by the hot pressing and spark plasma sintering methods. Two forms of aluminum oxide $\left(\alpha \mathrm{Al}_{2} \mathrm{O}_{3}\right.$ powder and electrocorundum) were used as a reinforcement. Microstructural investigations revealed that near fully dense materials with low porosity and a clear interface between the metal matrix and ceramics were obtained in the case of the SPS method. In this paper, the properties (mechanical, thermal, and tribological) of composite materials were also collected and compared. Technological tests were preceded by finite element method analyses of thermal stresses generated in the gradient structure, and additionally, the role of porosity in the formation process of composite properties was modeled. Based on the said modeling, technological conditions for obtaining FGMs were proposed.
\end{abstract}

Keywords functionally gradient materials, hot pressing, metal matrix composites, microstructure, spark plasma sintering, thermal conductivity

\section{Introduction}

Rapid progress in technology requires new materials with special properties. Composite materials are an answer to the constantly increasing demand for materials with improved structural and operating parameters, and enable required properties and features to be shaped deliberately to a degree unavailable for traditional types of monolithic materials. Metal matrix composites (MMCs) and functionally graded materials (FGMs) were developed to reach better parameters, especially high-temperature resistance to wear and corrosion, mechanical strength, thermal and electric conductivity, and magnetic properties. In particular, FGMs make suitable candidates for

This article is an invited submission to JMEP selected from presentations at the Symposium "Metal-Matrix Composites," belonging to the topic "Composite and Hybrid Materials" at the European Congress and Exhibition on Advanced Materials and Processes (EUROMAT 2015), held September 20-24, 2015, in Warsaw, Poland, and has been expanded from the original presentation.

Agata Strojny-Neqdza and Katarzyna Pietrzak, Institute of Electronic Materials Technology, 133 Wolczynska str., 01-919 Warsaw, Poland; and Witold Weglewski, Institute of Fundamental Technological Research, 5B Pawinski str., 02-106 Warsaw, Poland. Contact e-mail: agata.strojny@itme.edu.pl.

materials whose properties vary depending on the distance from the material surface (Ref 1). The idea of functionally graded materials was intensively developed in early 1984 in Japan, where it was proposed to increase adhesion and minimize the thermal stress in metal-ceramic composites developed for reusable rocket engines (Ref 2 ). At present, graded materials are widely used in power, aircraft, aerospace, electronics, automotive, and chemical industries (Ref 3$)$.

Copper is characterized by high electrical and thermal conductivity, which makes copper a great prospective component of metal matrix composite materials. However, poor adhesion to widely used reinforcements, chemical reactions at interfaces, and quick oxidization of $\mathrm{Cu}$ can create serious problems with the formation of the strong bonds at the interface between composite components (Ref 4, 5). Copper matrix composites with different ceramic reinforcements (AlN, SiC, C, $\mathrm{Al}_{2} \mathrm{O}_{3}$ ) are extensively used in aerospace industry in products that are subjected to severe thermal and mechanical loadings such as rocket thrusters and components in aircraft engines (Ref $6,7)$. A thruster is a drive unit of stabilizing motors used in rockets. It constitutes an element of an outlet in combustion engines, entered by gases from the combustion chamber. This particular part is exposed to the unfavorable impact of external factors such as high temperature, abrasive wear, and corrosion, hence being a frequently replaced element of the engine. The most common defects include layer degradation or numerous cracks resulting from a chemical reaction with exhaust gases (Ref 8). At present, a material used for thrusters is copper alloy, showing low resistance to wear. The application of a gradient material composed of $\mathrm{Cu}-\mathrm{Al}_{2} \mathrm{O}_{3}$ composite layers with a slight addition of aluminum oxide is expected to enhance tribological 
properties, at the same time preserving good thermal properties. The selection process of the composition of the gradient material was performed based on requirements for these materials (among others thermal conductivity higher than $300 \mathrm{~W} /(\mathrm{m} \cdot \mathrm{K})$, minimal porosity, high wear resistance), and additionally, it was intended to guarantee low residual stress in these systems.

It was reported that the physical and mechanical properties of composites are also improved significantly if particles are fine, and distribution of these particles is homogeneous and the metal-ceramics bonding is strong. The main disadvantage of copper matrix composites reinforced with aluminum oxide particles is residual porosity, which influences the material properties, and pores that are present within the area of the ceramic phase (Ref 9). One can observe that $\alpha$-form of aluminum oxide powder $\left(\alpha \mathrm{Al}_{2} \mathrm{O}_{3}\right)$ shows a strong tendency to form agglomerates at the preparation stage of $\mathrm{Cu}$ and $\mathrm{Al}_{2} \mathrm{O}_{3}$ powder mixtures, which results in residual porosity in composites. This is result of different sintering temperatures of copper and aluminum oxide. Electrocorundum is a polycrystalline material obtained by melting $\alpha \mathrm{Al}_{2} \mathrm{O}_{3}$ powder, referred to as corundum crystallized from an alloy in electric furnaces. It is pure, crystalline $\mathrm{Al}_{2} \mathrm{O}_{3}$ used to produce grinding wheels, abrasive paper, and cloth as well as high-melting and refractory materials. No crystalline free silica and heavy metals in its chemical composition makes it environmentally friendly and contributes to its protection. Another particularly crucial aspect is the production of an isotropic composite material, in which good metal-ceramic bonding will be obtained, without the third phase of the so-called nonstoichiometric compounds (spinels and oxides), which can significantly reduce the basic properties of these composites, including thermal conductivity.

The publication consists of two parts. The results of $\mathrm{Cu}$ $\mathrm{Al}_{2} \mathrm{O}_{3}$ composites sintering by hot pressing (HP) and spark plasma sintering (SPS) in first have been presented. The second section has been focused on production process of gradient materials (FGM), assignment to racket thruster. To optimize the stress distribution in the established models, finite element method (FEM) has been used. Based on the FEM results, the compositions of FGM materials have been accepted.

In this paper, the effect of volume fraction and type of the $\mathrm{Al}_{2} \mathrm{O}_{3}$ form on the microstructure and some chosen properties (hardness, thermal conductivity, bending strength, and wear resistance) was also reported.

\section{Experimental Procedure}

The following commercially available powders were used as the starting materials: copper powder (Fig. 1a, by Sigma Aldrich, 99.9\% purity) and two kinds of alumina powders: electrocorundum powder ( $\mathrm{ED} \mathrm{Al}_{2} \mathrm{O}_{3}$ ) (Fig. 1b, KOS, 99\% purity) and $\alpha$-form of aluminum oxide powder $\left(\alpha \mathrm{Al}_{2} \mathrm{O}_{3}\right)$ (Fig. 1c, NewMet, $99.99 \%$ purity). These two forms were chosen to determine the effect of the ceramic phase on the properties of composite materials. Research tasks included the characterization of the grain size distribution of the output powders performed using the Clemex image analysis system. The particle size distribution was analyzed as a function of Feret's diameter $(d)$. As a result, the average Feret's diameter $\left(d_{\mathrm{A}}\right)$ was calculated. Based on the analysis, the average size of the $\mathrm{Cu}$ particles was found to be $d_{\mathrm{Cu}}=9 \mu \mathrm{m}$ (the size range is from 2 to $11 \mu \mathrm{m}$ ), and that of the $\alpha \mathrm{Al}_{2} \mathrm{O}_{3}$ particles equaled $d_{\alpha \mathrm{Al} 2 \mathrm{O} 3}=2.4 \mu \mathrm{m}$ (from 1 to $5 \mu \mathrm{m}$ ), whereas for the $\mathrm{ED} \mathrm{Al}_{2} \mathrm{O}_{3}$ particles, $d_{\mathrm{EDAl} 2 \mathrm{O} 3}=2.5 \mu \mathrm{m}$ (from 0.9 to $4.5 \mu \mathrm{m}$ ).

Three different powder mixtures were prepared with the following composition (in vol. $\%$ ): $99 \% \mathrm{Cu}-1 \% \mathrm{Al}_{2} \mathrm{O}_{3}, 97 \% \mathrm{Cu}-$ $3 \% \mathrm{Al}_{2} \mathrm{O}_{3}$, and $95 \% \mathrm{Cu}-5 \% \mathrm{Al}_{2} \mathrm{O}_{3}$. These compositions were selected based on modeling studies (FEM model) focused on thermal stress in the gradient structure of composite materials, taking into consideration their possible application in aerospace industry, including rocket thrusters. One of the very popular
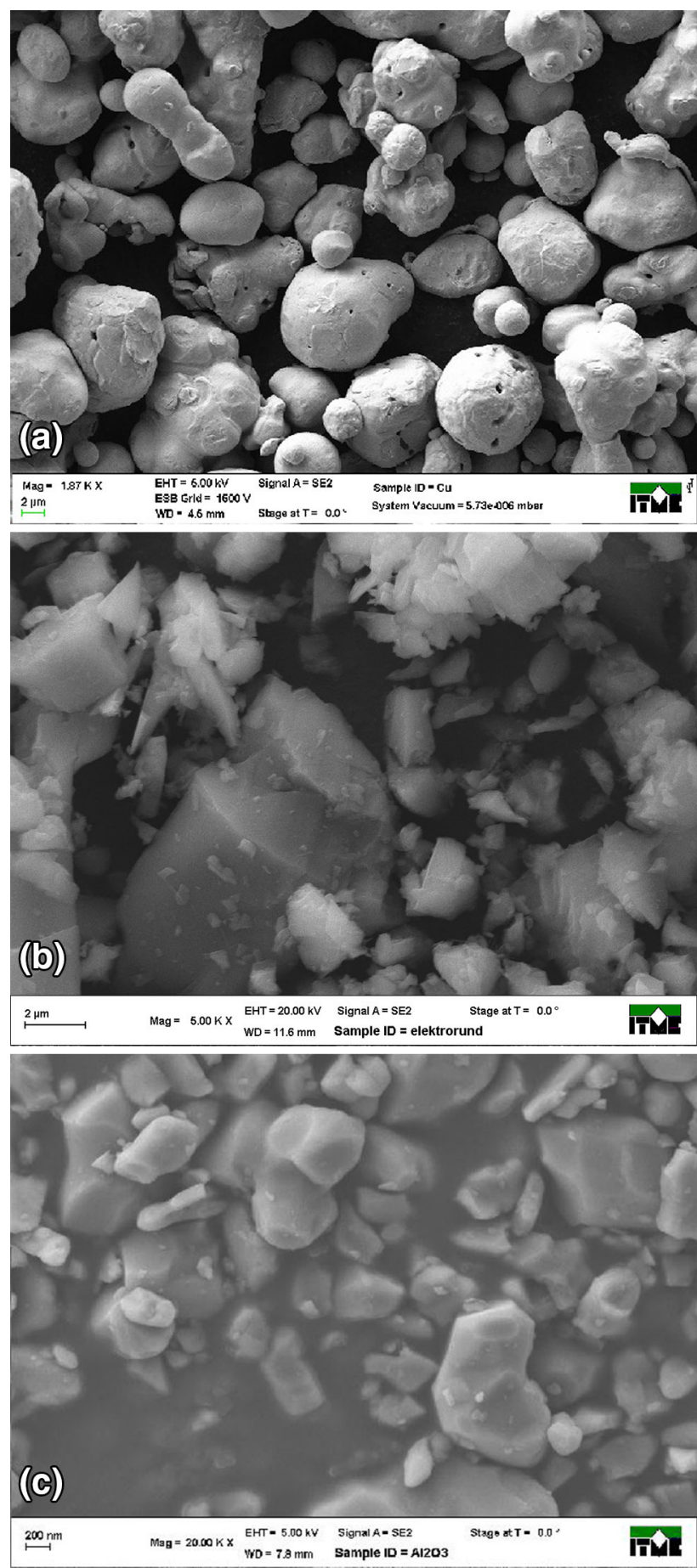

Fig. 1 SEM images of starting materials: (a) $\mathrm{Cu}$, (b) $\mathrm{ED} \mathrm{Al}_{2} \mathrm{O}_{3}$, and (c) $\alpha \mathrm{Al}_{2} \mathrm{O}_{3}$ 
methods of preparing metal-ceramic composite powders is mechanical alloying proposed by Banjamin (Ref 10,11) in the 1960 s, which was followed in the present experiment. The mixing test was carried out in a Pulverisette 6/Fritsch planetary mill with a $250 \mathrm{~mL}$ container and tungsten carbide balls (Ø 5 $\mathrm{mm}$ ). The high-energy mechanical milling process was performed at room temperature under an air atmosphere, at the rotation speed of $200 \mathrm{rpm}$ and the time of mixing of $6 \mathrm{~h}$. The weight ratio of balls to powder (BPR) was 3:1. Mixing process parameters were experimentally selected based on the previous works by the authors (Ref 11,12$)$.

The history of mixing kinetics can be illustrated by means of the coordinates of powder particle diameter and standard deviation. Temporal changes of these two parameters can get a specific "hysteresis"-loop or are linear. It suggests either growth (agglomeration) of particles of the composite powder
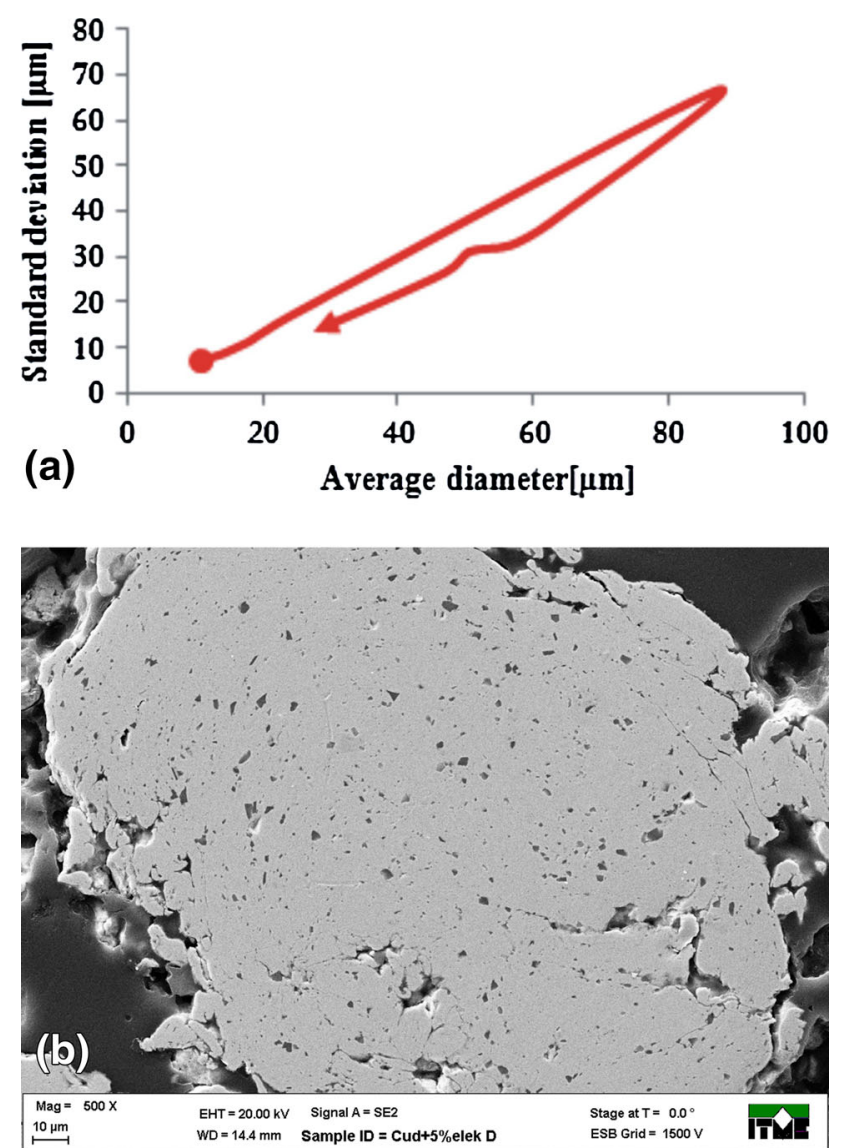

Fig. 2 Time evolution of estimated particle size distribution for $\mathrm{Cu}$ 5 vol.\% ED $\mathrm{Al}_{2} \mathrm{O}_{3}$ system (a) and optical microscope image of microsection of composite powder in epoxy resin (b) materials or decomposition of particles matrix without the formation of composite powders. This effect is usually observed for high concentrations of the fragile reinforcing phase. This is confirmed by the performed research works focused on graining of copper-5\% electrocorundum powders (Fig. 2a), which was mixed in a high-energy planetary mill.

The results of mechanical work done on the mill system are observed as powder particles growing in diameter. When the concentration of the reinforcing phase reaches the saturation point in the matrix, the formation process of composite powder, are going through breaking of matrix, gradual grinding, and production of high homogeneous in size composite powder (Fig. 2b). The obtained materials were pressure sintered in the Astro Thermal Technology hot press. The parameters of sintering were as follows: sintering temperature of $1050^{\circ} \mathrm{C}$, time of $30 \mathrm{~min}$, and pressure of $30 \mathrm{MPa}$. After the holding time (30 $\mathrm{min}$ ), the samples were cooled down from the furnace temperature to the room temperature, with the external load removed. Spark plasma sintering (SPS) was also used to sinter composite powders consisting of copper and electrocorundum powders. The parameters of the process were as follows: temperature of $950^{\circ} \mathrm{C}$, time of $15 \mathrm{~min}$, and pressure of $30 \mathrm{MPa}$.

Microstructural investigations included analyses using scanning electron microscopy (SEM, Auriga CrossBeam Workstation/Zeiss) and transmission microscopy (TEM, Tecnai G2 F20). The density of the obtained composites was measured according to the Archimedes method. The theoretical density was calculated on the basis of the densities of $\mathrm{Al}_{2} \mathrm{O}_{3}$ $\left(\rho_{\mathrm{Al}_{2} \mathrm{O}_{3}}=3.97 \mathrm{~g} / \mathrm{cm}^{3}\right)$ and copper $\left(\rho_{\mathrm{Cu}}=8.97 \mathrm{~g} / \mathrm{cm}^{3}\right)$. Hardness (HV1) was tested by Durascan 10/Emcotest with a Vickers diamond indenter using a load of $9.81 \mathrm{~N}$ applied for $10 \mathrm{~s}$. The hardness results were averaged over 5 indentations per specimen. Thermal conductivity was measured at the temperature of $50^{\circ} \mathrm{C}$ using the Laser Flash Analyser LFA457/Netzsch under an argon atmosphere. The measurements of the specific heat (used in the calculation of thermal conductivity) of the composites were performed by a STA 449 Jupiter Netzsch fine thermal analyzer using the differential scanning calorimetric method with heat flow (DSC). The bending strength of the composite samples was determined in a ZWICK 1446 testing machine with a $30 \mathrm{~mm}$ span and a head travel speed of $10 \mathrm{~mm} /$ min. The average values of the bending strength were calculated taking in consideration the results of five tests. Tribological tests were conducted according to the following procedure. The samples were pressed against a stainless steel ball measuring $6.5 \mathrm{~mm}$ in diameter with force $F_{\mathrm{n}}=5 \mathrm{~N}$. A holder together with the ball attached to it was set in a reciprocating motion driven by an electrodynamic generator. The two components between which the friction appeared slid on one another at a velocity of $5 \mathrm{~mm} / \mathrm{s}$. The friction force $F_{\mathrm{t}}$ thus generated was measured with a piezoelectric displacement

Table 1 Material properties used in modeling (Ref 10, 11)

Properties

Ceramic $\left(\mathrm{Al}_{2} \mathrm{O}_{3}\right)$

Copper $(\mathrm{Cu})$

Young's modulus, GPa

Poisson's ratio

Coefficient of thermal expansion, $1 / \mathrm{K}$

Specific heat, $\mathrm{J} /(\mathrm{kg} \cdot \mathrm{K})$

Coefficient of thermal conduction, $\mathrm{W} /(\mathrm{m} \cdot \mathrm{K})$

Density, $\mathrm{kg} / \mathrm{m}^{3}$

320
0.2
$6.5 \times 10^{-6}$
800
18
3970

114

0.35

$16.5 \times 10^{-6}$

380

395

8970 

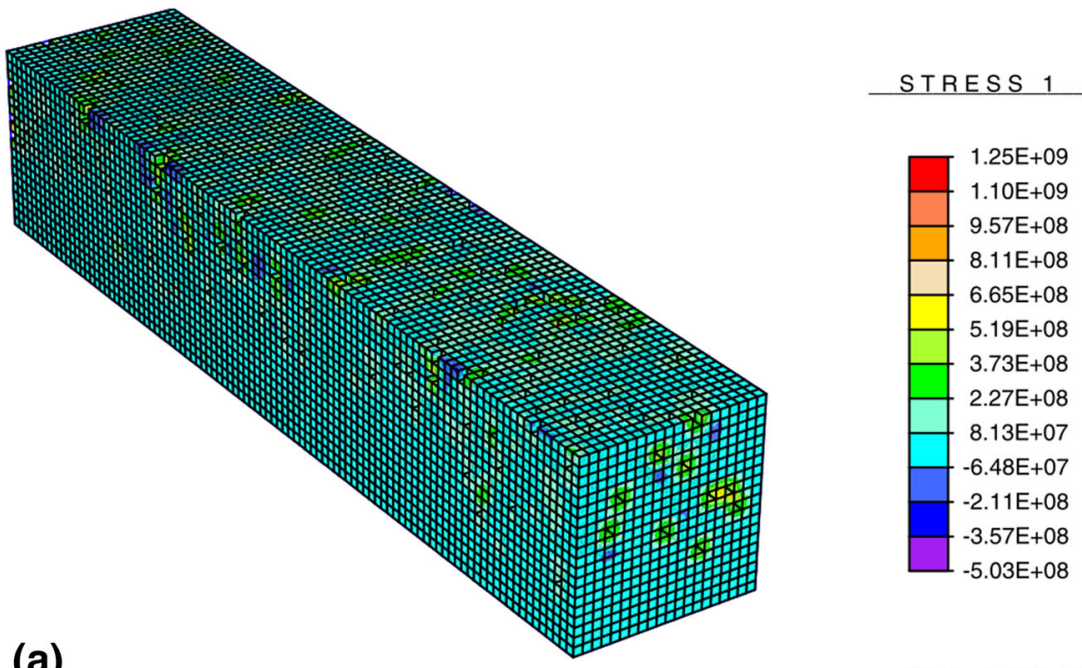

(a)

Time $=1.00 \mathrm{E}+04$

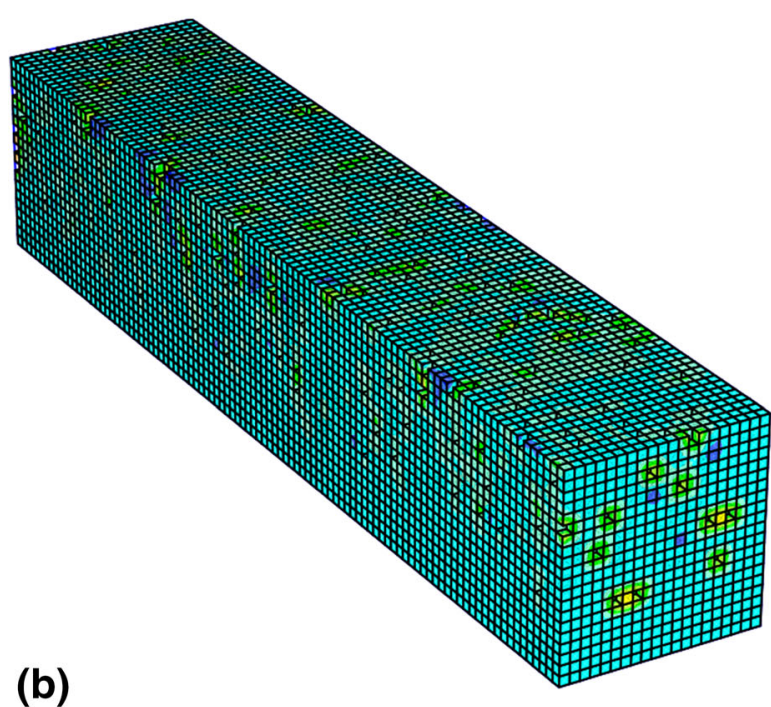

STRESS 1

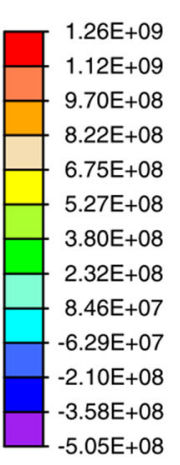

Time $=1.00 \mathrm{E}+04$

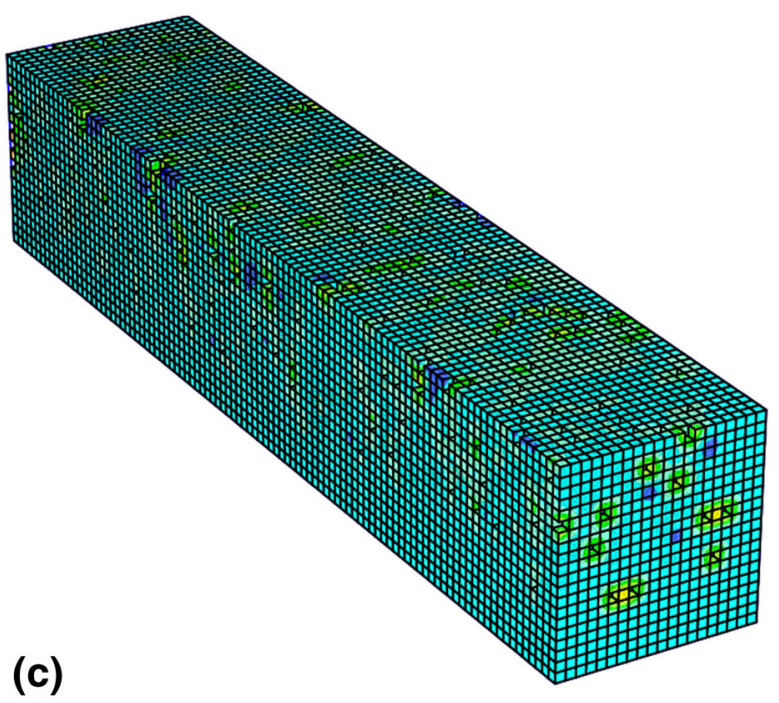

STRESS 1

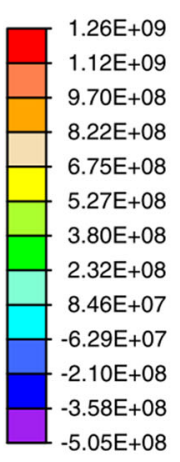

Time $=1.00 \mathrm{E}+04$

Fig. 3 The thermal stress inside the copper phase of FGM; (a) FGM 1, (b) FGM 2, (c) FGM 3 


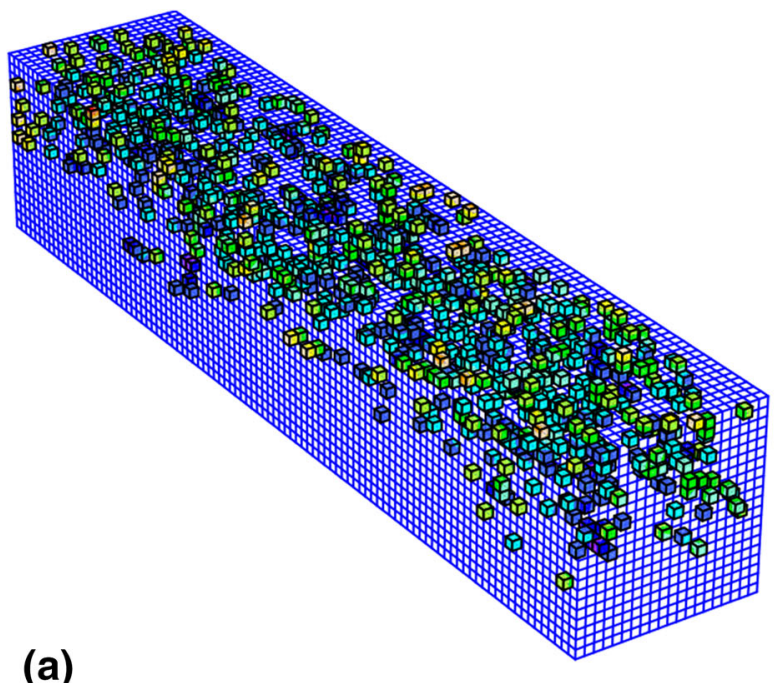

(a)

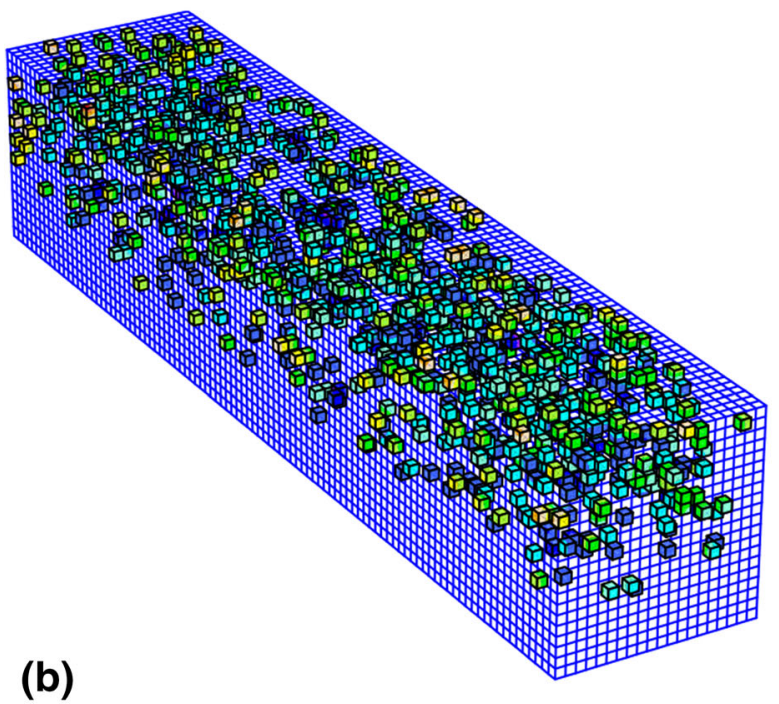

(b)

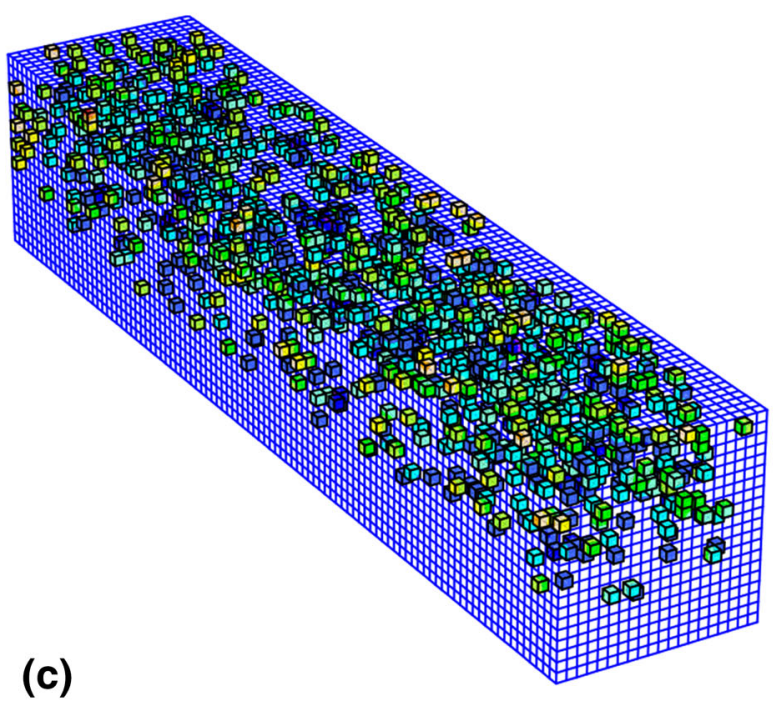

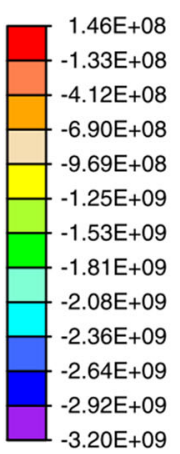

Time $=1.00 \mathrm{E}+04$

STRESS 1

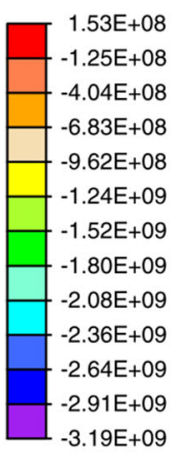

Time $=1.00 \mathrm{E}+04$

STRESS 1

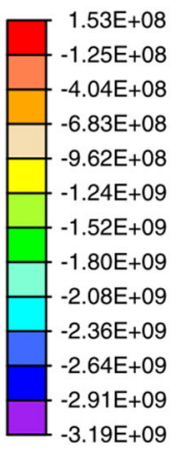

Time $=1.00 \mathrm{E}+04$

Fig. 4 The thermal stress inside the alumina phase of FGM; (a) FGM 1, (b) FGM 2, (c) FGM 3 


\begin{tabular}{|c|c|c|c|c|c|c|c|c|}
\hline & & \multicolumn{3}{|c|}{ Average stress in whole material } & \multicolumn{2}{|c|}{ Stress in copper phase } & \multicolumn{2}{|c|}{ Stress in alumina phase } \\
\hline & & $\sigma_{11}, \mathbf{M P a}$ & $\sigma_{22}, \mathbf{M P a}$ & $\sigma_{33}, \mathbf{M P a}$ & Max stress & Min stress & Max stress & Min stress \\
\hline \multirow[t]{4}{*}{ FGM No. 1} & Layer $1\left(0 \% \mathrm{Al}_{2} \mathrm{O}_{3}\right)$ & 182.63 & 4.21 & 0.0008 & 189.18 & 26.66 & $\ldots$ & $\ldots$ \\
\hline & Layer $2\left(1 \% \mathrm{Al}_{2} \mathrm{O}_{3}\right)$ & 185.09 & 1.87 & 0.0003 & 213.83 & 18.39 & 176.62 & 0 \\
\hline & Layer $3\left(3 \% \mathrm{Al}_{2} \mathrm{O}_{3}\right)$ & 199.34 & 0.31 & 0.0001 & 239.28 & 13.91 & 718.09 & -103.11 \\
\hline & Layer $4\left(5 \% \mathrm{Al}_{2} \mathrm{O}_{3}\right)$ & 207.19 & 1.14 & 0.0 & 319.22 & 9.12 & 1049.1 & -171.48 \\
\hline \multirow[t]{4}{*}{ FGM No. 2} & Layer $1\left(0 \% \mathrm{Al}_{2} \mathrm{O}_{3}\right)$ & 192.18 & 21.10 & 1.21 & 216.09 & 16.01 & $\ldots$ & $\ldots$ \\
\hline & Layer $2\left(2 \% \mathrm{Al}_{2} \mathrm{O}_{3}\right)$ & 211.82 & 9.17 & 0.001 & 232.21 & 8.43 & 199.12 & 0 \\
\hline & Layer $3\left(3.5 \% \mathrm{Al}_{2} \mathrm{O}_{3}\right)$ & 219.01 & 4.45 & 0.0 & 250.15 & 4.03 & 601.15 & -111.76 \\
\hline & Layer $4\left(5 \% \mathrm{Al}_{2} \mathrm{O}_{3}\right)$ & 239.49 & 5.59 & 0.0 & 333.82 & 2.44 & 1129.9 & -209.23 \\
\hline \multirow[t]{4}{*}{ FGM No. 3} & Layer $1\left(0 \% \mathrm{Al}_{2} \mathrm{O}_{3}\right)$ & 199.33 & 23.49 & 0.91 & 216.80 & 17.33 & $\ldots$ & $\ldots$ \\
\hline & Layer $2\left(2 \% \mathrm{Al}_{2} \mathrm{O}_{3}\right)$ & 231.01 & 10.31 & 0.0 & 270.29 & 9.19 & 218.52 & 0 \\
\hline & Layer $3\left(4 \% \mathrm{Al}_{2} \mathrm{O}_{3}\right)$ & 240.48 & 5.19 & 0.0 & 291.83 & 2.12 & 993.13 & -188.18 \\
\hline & Layer $4\left(5 \% \mathrm{Al}_{2} \mathrm{O}_{3}\right)$ & 259.39 & 8.16 & 0.0 & 388.02 & 1.94 & 1459.3 & -249.37 \\
\hline
\end{tabular}

Table 3 Physical and mechanical properties of copper and $\mathrm{Cu}-\alpha \mathrm{Al}_{2} \mathrm{O}_{3}, \mathrm{Cu}-\mathrm{ED} \mathrm{Al}_{2} \mathrm{O}_{3}$ composites

\begin{tabular}{|c|c|c|c|c|c|c|c|}
\hline $\begin{array}{l}\text { Material } \\
\text { composition, vol. } \%\end{array}$ & Method & $\begin{array}{c}\text { Measured } \\
\text { density, } \mathrm{g} / \mathrm{cm}^{3}\end{array}$ & $\begin{array}{c}\text { Relative } \\
\text { density, \% }\end{array}$ & $\begin{array}{c}\text { Hardness } \\
\text { HV1 }\end{array}$ & $\begin{array}{c}\text { Specific heat, } \\
\mathbf{J} /(\mathrm{g} \cdot \mathrm{K})\end{array}$ & $\begin{array}{c}\text { Thermal } \\
\text { conductivity, W/(m·K) }\end{array}$ & $\begin{array}{c}\text { Bending } \\
\text { strength, MPa }\end{array}$ \\
\hline \multirow[t]{2}{*}{$\mathrm{Cu}$} & HP & 8.72 & 97.2 & $39.7 \pm 3.0$ & $0.39 \pm 0.01$ & $355.2 \pm 4.1$ & $\ldots$ \\
\hline & SPS & 8.89 & 99.1 & $40.2 \pm 2.2$ & $0.40 \pm 0.01$ & $360.4 \pm 2.0$ & $\ldots$ \\
\hline $\mathrm{Cu}-1 \% \alpha \mathrm{Al}_{2} \mathrm{O}_{3}$ & HP & 8.61 & 96.9 & $42.9 \pm 0.8$ & $0.41 \pm 0.01$ & $321.5 \pm 1.2$ & $289.5 \pm 3.4$ \\
\hline $\mathrm{Cu}-3 \% \alpha \mathrm{Al}_{2} \mathrm{O}_{3}$ & HP & 8.50 & 96.7 & $44.7 \pm 0.5$ & $0.41 \pm 0.01$ & $316.4 \pm 1.1$ & $268.1 \pm 5.4$ \\
\hline $\mathrm{Cu}-5 \% \alpha \mathrm{Al}_{2} \mathrm{O}_{3}$ & $\mathrm{HP}$ & 8.30 & 95.6 & $50.0 \pm 0.3$ & $0.42 \pm 0.01$ & $296.5 \pm 1.4$ & $210.3 \pm 3.9$ \\
\hline \multirow[t]{2}{*}{$\mathrm{Cu}-1 \% \mathrm{ED} \mathrm{Al}{ }_{2} \mathrm{O}_{3}$} & $\mathrm{HP}$ & 8.59 & 96.8 & $42.1 \pm 2.4$ & $0.40 \pm 0.01$ & $333.5 \pm 2.2$ & $299.6 \pm 6.4$ \\
\hline & SPS & 8.75 & 98.6 & $56.1 \pm 1.2$ & $0.41 \pm 0.01$ & $335.1 \pm 4.1$ & $\ldots$ \\
\hline \multirow[t]{2}{*}{$\mathrm{Cu}-3 \% \mathrm{ED} \mathrm{Al} \mathrm{Al}_{2} \mathrm{O}_{3}$} & HP & 8.51 & 97.0 & $43.1 \pm 1.8$ & $0.42 \pm 0.01$ & $315.2 \pm 2.8$ & $284.1 \pm 4.9$ \\
\hline & SPS & 8.69 & 99.1 & $60.1 \pm 2.8$ & $0.42 \pm 0.01$ & $316.2 \pm 4.3$ & $\ldots$ \\
\hline \multirow[t]{2}{*}{$\mathrm{Cu}-5 \% \mathrm{ED} \mathrm{Al}_{2} \mathrm{O}_{3}$} & HP & 8.40 & 96.4 & $54.7 \pm 3.4$ & $0.44 \pm 0.01$ & $303.5 \pm 1.6$ & $273.7 \pm 5.6$ \\
\hline & SPS & 8.60 & 99.0 & $68.2 \pm 1.8$ & $0.43 \pm 0.01$ & $305.4 \pm 2.0$ & $\ldots$ \\
\hline
\end{tabular}

sensor 24 times per second. It was induced and recorded in 30 min long friction processes. The friction coefficient was analyzed using special software. After the test, the surface of the groove was analyzed using scanning electron microscopy, and wear volume of the groove of the samples was measured with a scanning profile-gage (Veeco).

\section{Results and Discussion}

\subsection{Selection of Composition of Gradient Material: FEM Modeling}

Selection of the composition of the $\mathrm{Cu}-\mathrm{Al}_{2} \mathrm{O}_{3}$ composite was made through optimization of the state and distribution of thermal stresses in a gradient material using the finite element method (to determine thermal stresses generated in a material in a standard operation mode of a given structural component).

In this modeling approach, a simplified FEM model was used. The FE mesh was generated as a randomly immersed voxel of alumina in the metal matrix. The following alumina content was considered:

1. $0,1,3$, and $5 \%$ of $\mathrm{Al}_{2} \mathrm{O}_{3}$ content for the first, second, third, and fourth layer, respectively-FGM 1,
2. $0,2,3.5$, and $5 \%$ of $\mathrm{Al}_{2} \mathrm{O}_{3}$ content for the first, second, third, and fourth layer, respectively-FGM 2,

3. $0,2,4$, and $5 \%$ of $\mathrm{Al}_{2} \mathrm{O}_{3}$ content for the first, second, third, and fourth layer, respectively-FGM 3.

For the purpose of numerical calculation, material parameters were taken from the literature (Ref 13, 14) and subsequently are presented in Table 1 . In this numerical experiment, the calculation of the thermal stress inside the material was made for the cooling temperature ranging from $1000^{\circ} \mathrm{C}$ to room temperature $\left(20^{\circ} \mathrm{C}\right)$ with the blocked displacement on the sides of the specimen. The examples of calculated thermal stresses are presented in Fig. 3 for the copper phase and in Fig. 4 for the alumina phase. The average stress was calculated according to the following Eq 1:

$\sigma_{i i}^{\mathrm{avg}}=\sum_{j=1}^{n} \frac{\sigma_{i i}^{j}}{n}$,

where $n$ is the number of elements and $\sigma_{i i}^{j}$ stands for the stress $\sigma_{11}, \sigma_{22}$, and $\sigma_{33}$ in the $j$ th element.

The calculation results of average thermal residual stresses (residual stress tensor in three directions) are presented in Table 2. The stress in the layer is generated by the mismatch between the coefficient of thermal expansion of copper and 

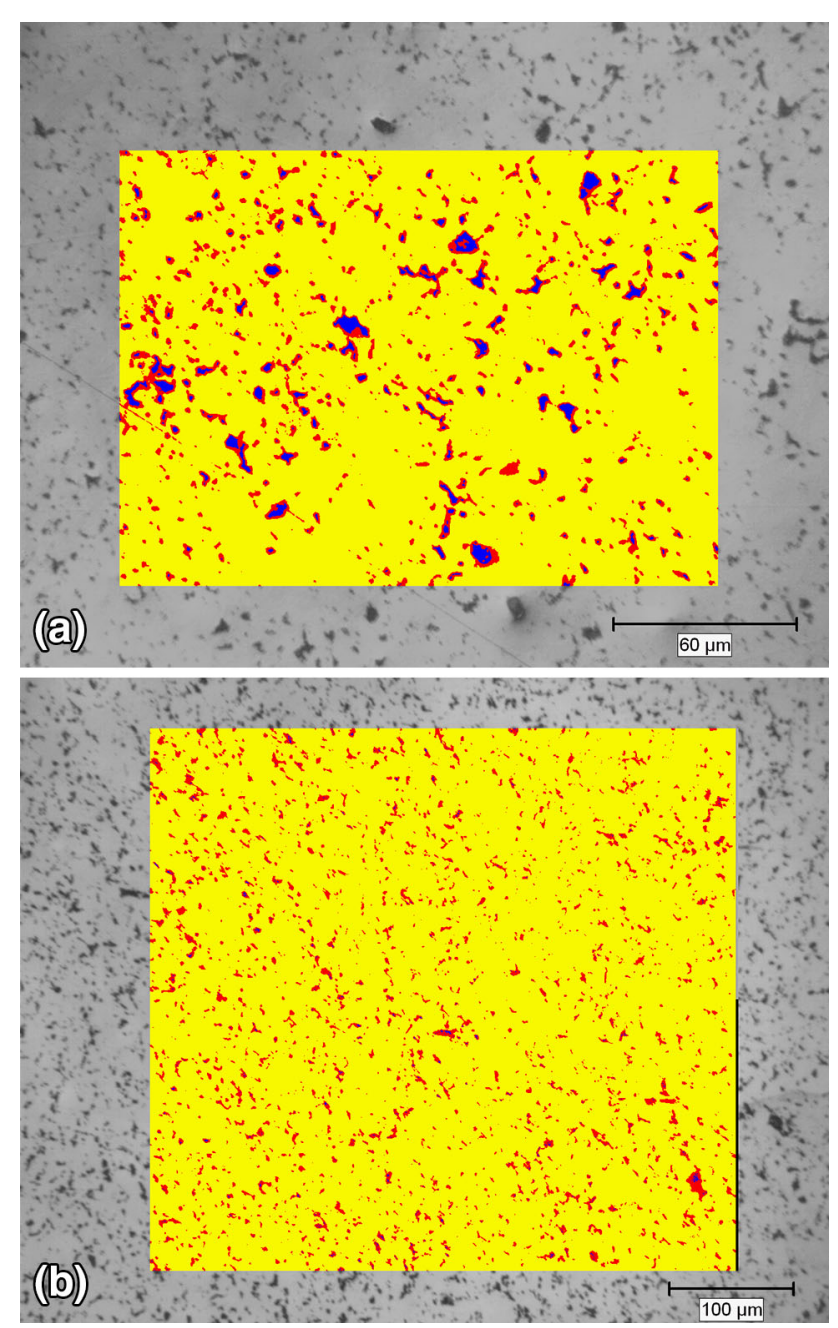

Fig. 5 Porosity analysis for the following composite materials: (a) $\mathrm{Cu}-5$ vol.\% $\alpha_{\mathrm{Al}_{2} \mathrm{O}_{3}}$ (HP) and (b) $\mathrm{Cu}-5$ vol.\% $\mathrm{ED} \mathrm{Al}_{2} \mathrm{O}_{3}$ (HP); color-ceramic phase, yellow-metallic phase, blue-porosity (Color figure online)

alumina, but on the level of thermal stress, the boundary conditions have a large influence. Here blocked was the displacement (in direction 11) on the both sides of specimen, and even in the pure copper, this leads to generation of stress. The addition of even small content of alumina leads to increase the thermal stress (Table 2) ( $\sigma_{11}$ for layer 1 compared to $\sigma_{11}$ for layer 2, 3, or 4). The $\sigma_{22}$ and $\sigma_{33}$ are lover then $\sigma_{11}$ because the displacement for those directions had not been blocked-the specimen is free to expand in those two directions. The calculations made show that the lowest values and therefore the lowest difference in values between the first and the second layers within the gradient area were obtained for the first model of the gradient material, i.e., $0,1,3$, and $5 \%$ of $\mathrm{Al}_{2} \mathrm{O}_{3}$ content for the first, the second, and the third layers-FGM 1. In connection with the obtained results, such gradient structure was assumed for the purpose of experimental works.

\subsection{Physical and Mechanical Properties of Composite Materials}

The physical and mechanical properties of the obtained composite materials are presented in Table 3. The measured and relative densities of pure copper, $\mathrm{Cu}-\mathrm{Al}_{2} \mathrm{O}_{3}$ composites
(HP), and Cu-electrocorund composites (SPS) show better densification of a material for spark plasma sintering (SPS). A better densification of composites obtained through the SPS process compared to hot-pressed materials is due to the idea of both processes, i.e., the manner in which the graphite matrix where the sintered powder is placed is heated up. For the HP method, the heat is transferred to the matrix through convection and radiation. Therefore, the distribution of temperature on the cross section of the sample is uneven, and longer times are required to obtain heterogeneity. As for the SPS method, the set electrical current that passes through graphite plugs, the matrix, and the sintered powder heats the whole system due to the effect of Joule heating. As a result, a local temperature hike on grain-to-grain contact sites is observed (again due to the effect of Joule heating). This has an effect on the speed of the mass transport on the way of evaporation and convection, and, at the same time, oxides are removed from the surface of metal particles and the energy of activation of diffusion processes in the powder is decreased, which improves the densification of the material. The density tests confirmed the possibility of obtaining nearly theoretically dense $\mathrm{Cu}-\mathrm{ED} \mathrm{Al}_{2} \mathrm{O}_{3}$ composites using SPS method. Additionally, the obtained results reveal higher relative density for composites with electrocorundum phase (especially with 5 vol.\% of ceramic phase) then in the case of using $\alpha \mathrm{Al}_{2} \mathrm{O}_{3}$. When using electrocorundum grains as a composite reinforcement, intergranular porosity occurring between nonsintered grains of $\alpha \mathrm{Al}_{2} \mathrm{O}_{3}$ powder displaying a strong tendency to agglomerate was successfully eliminated. The performed CLEMEX porosity analysis of composite materials (Fig. 5) showed that the porosity is located within the area of the ceramic phase, which in addition is easily crumbled up during the preparation of microsection surfaces due to the fact that $\alpha \mathrm{Al}_{2} \mathrm{O}_{3}$ grains are not sintered under the production conditions of composites. Porosity in the copper matrix was also observed for composites sintered using the hot pressing technique (HP). $<$ Dummy RefID="Fig5

The research works carried out with the CLEMEX method enabled the estimation of porosity in particular composites. By the way of illustration, for $\mathrm{Cu}-5 \% \alpha \mathrm{Al}_{2} \mathrm{O}_{3}$ composite, porosity reached around $4 \%$, whereas for $\mathrm{Cu}-5 \% \mathrm{ED} \mathrm{Al}_{2} \mathrm{O}_{3}$, it equaled about $2 \%$. The obtained results correlate closely with density measurements.

In the case of hardness measurements for the $\mathrm{Cu}-\mathrm{Al}_{2} \mathrm{O}_{3}$ composites (Table 3), the increase of ceramic phase causes the raise of materials hardness. The form of reinforcement strongly influence on the obtained values. Electrocorundum as a melted form of $\alpha \mathrm{Al}_{2} \mathrm{O}_{3}$ powder significantly improve of hardness of bulk composite, what is clearly visible in the case of materials sintered by SPS method. Considerably higher hardness values were achieved for composites obtained by the SPS technique, in the case of which electrocorundum was used as the ceramic phase. HV1 hardnesses for the composite with 5 vol.\% of electrocorundum for sinters obtained by the SPS method and the HP technique were 68.2 and 54.7, respectively, as compared with pure copper with the HV1 value of 40. Comparing the results for HP method, it is not that obvious. There are not too much differences depending on the type of ceramic phase. The role of porosity (the values are comparable) may have the critical effect of the obtained results. We can add that measurements of hardness for materials with so slight amount of reinforcement are difficult and obtained results may be confusing.

The performed bending strength tests (Table 3) prove that when increasing the amount of aluminum oxide in composites, 

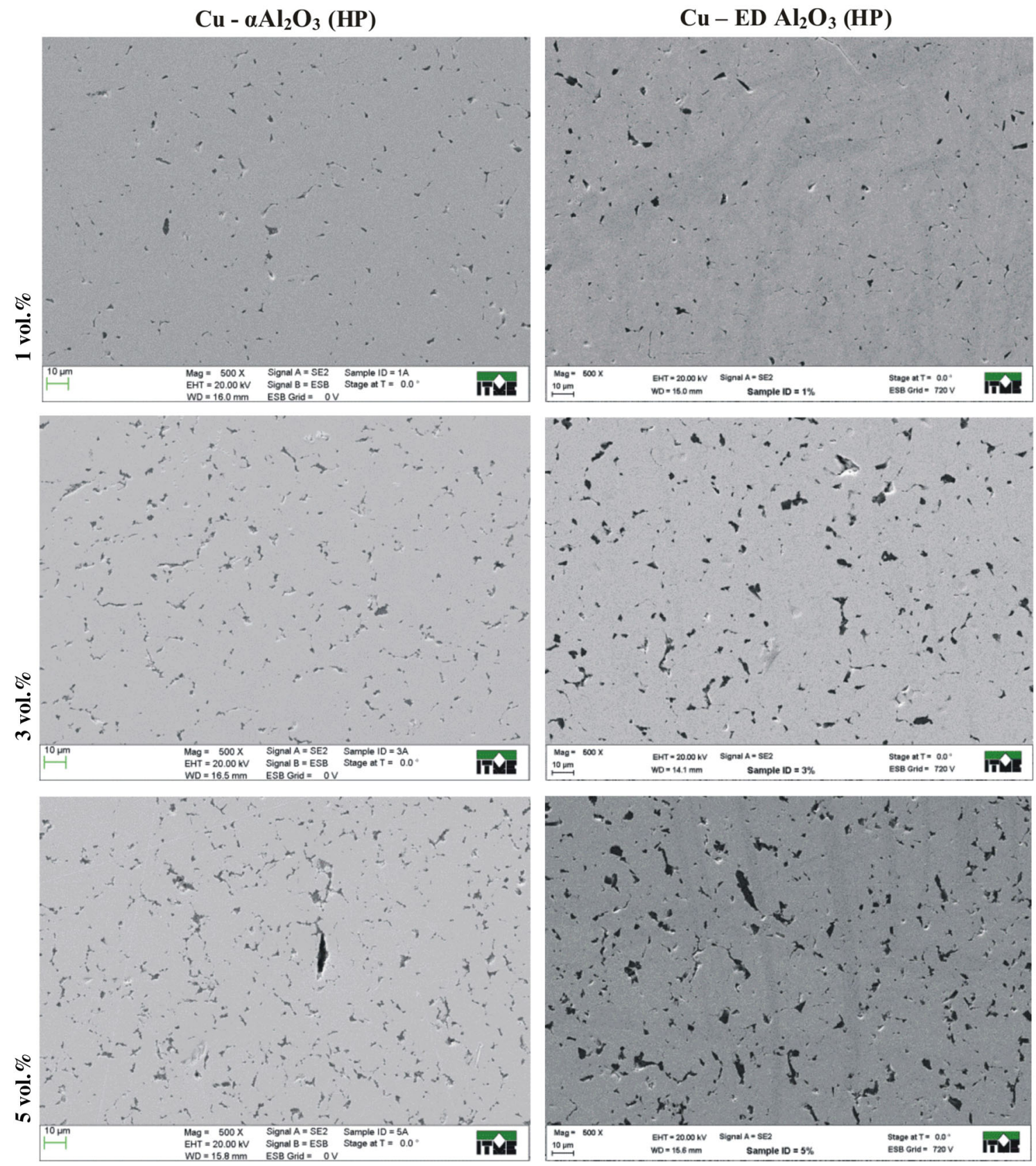

Fig. 6 SEM images of $\mathrm{Cu}-\mathrm{Al}_{2} \mathrm{O}_{3}$ composite materials obtained by hot pressing method (HP)

their strength falls. This decrease is a consequence of an increased fraction of the fragile ceramic phase. Higher values of bending strength were recorded for composites in which electrocorundum phase was used. Among others, such results can be explained by a more advantageous reinforcing phase distribution in the matrix. In the case of $\mathrm{Cu}-\alpha \mathrm{Al}_{2} \mathrm{O}_{3}$ composites, agglomerates of nonsintered aluminum oxide powder, recognized as areas with lower strength, are formed in the structure. The tendency of bending strength changes is appropriate, but we are aware of imperfection of this test, especially when we measure materials of high plasticity (like copper).

The analysis of the thermal properties of $\mathrm{Cu}-\mathrm{Al}_{2} \mathrm{O}_{3}$ composites confirmed an influence of the chemical composition, type of the applied powder as well as their manufacturing technique on the obtained thermal conductivity values (Table 3). Higher thermal diffusivity values were achieved for composite materials sintered using the SPS method. In consequence, thermal conductivity of these materials is greater in the case of composites obtained by the hot pressing technique (HP). The presence of pores in the structure of composites fundamentally affects the obtained thermal conductivity values. Pores present between nonsintered aluminum oxide grains are barriers for the heat transport in a material. This study confirms the previous works by the authors (Ref 15), focused on a different reinforcement material (AIN), in the case of which similar problems were observed. 
(a)

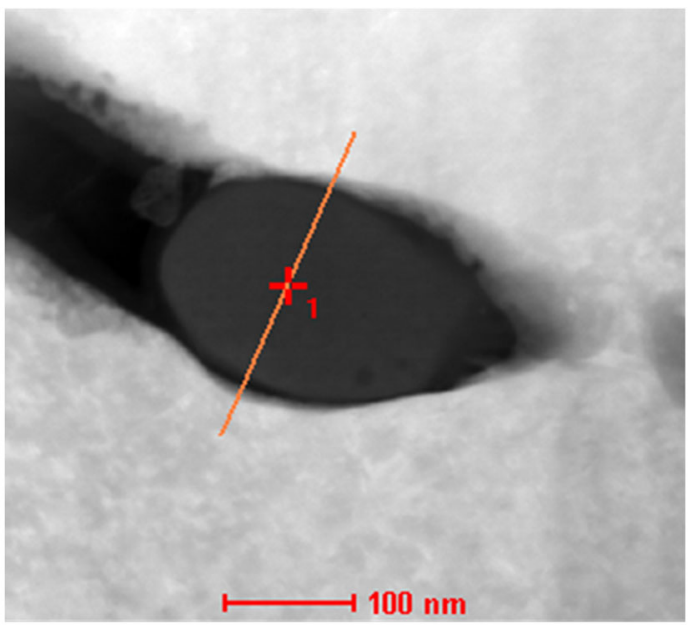

(b)

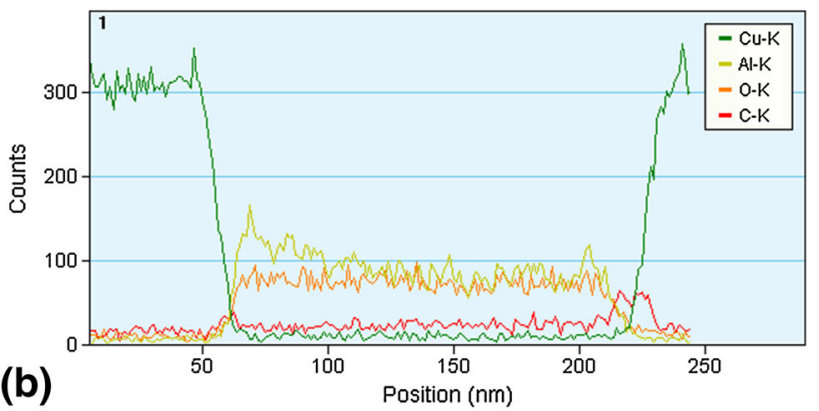

Fig. 7 Scanning transmission electron micrograph (a) and linear elements distribution (b) in $\mathrm{Cu}-5$ vol. $\% \alpha \mathrm{Al}_{2} \mathrm{O}_{3}$ (HP)

For $\mathrm{Cu}-\mathrm{Al}_{2} \mathrm{O}_{3}$ composites in which electrocorundum was used, thermal conductivity $>300 \mathrm{~W} /(\mathrm{m} \cdot \mathrm{K})$ was successfully obtained for all proposed compositions. However wondering, there is slight increase in thermal conductivity with respect to the improvement of the density of composites wit 1 and $3 \%$ of ceramic phase. The highest thermal conductivity value of 335 $\mathrm{W} /(\mathrm{m} \cdot \mathrm{K})$ was recorded for the $\mathrm{Cu}-1$ vol.\% electrocorundum composite (SPS). An increased ceramic phase fraction in composites results in the expected decrease in thermal conductivity of composites. This is inextricably linked with an increased fraction of the phase with the lowest thermal conductivity $(\lambda \approx 20-30 \mathrm{~W} /(\mathrm{m} \cdot \mathrm{K}))(\operatorname{Ref} 13)$.

\subsection{Microstructure Investigation of Composite Materials (SEM/EDS and TEM)}

Research on the microstructure of $\mathrm{Cu}-\alpha_{\mathrm{Al}} \mathrm{O}_{3}$ and $\mathrm{Cu}-\mathrm{ED}$ $\mathrm{Al}_{2} \mathrm{O}_{3}$ composites using scanning microscopy was focused on the assessment of the quality of bonding between ceramics grains and the copper matrix as well as the quality of the obtained material, i.e., distribution homogeneity of the reinforcing phase and absence of any defects which could have a significant influence on mechanical and thermal properties of the composites. The SEM images of HP composites materials in Fig. 6 are presented.

The analysis of the microstructure found quite uniform distribution of reinforcing phase in the whole volume of the composite. Outside the porosity there were no other significant discontinuities in the structure of the obtained materials. For the
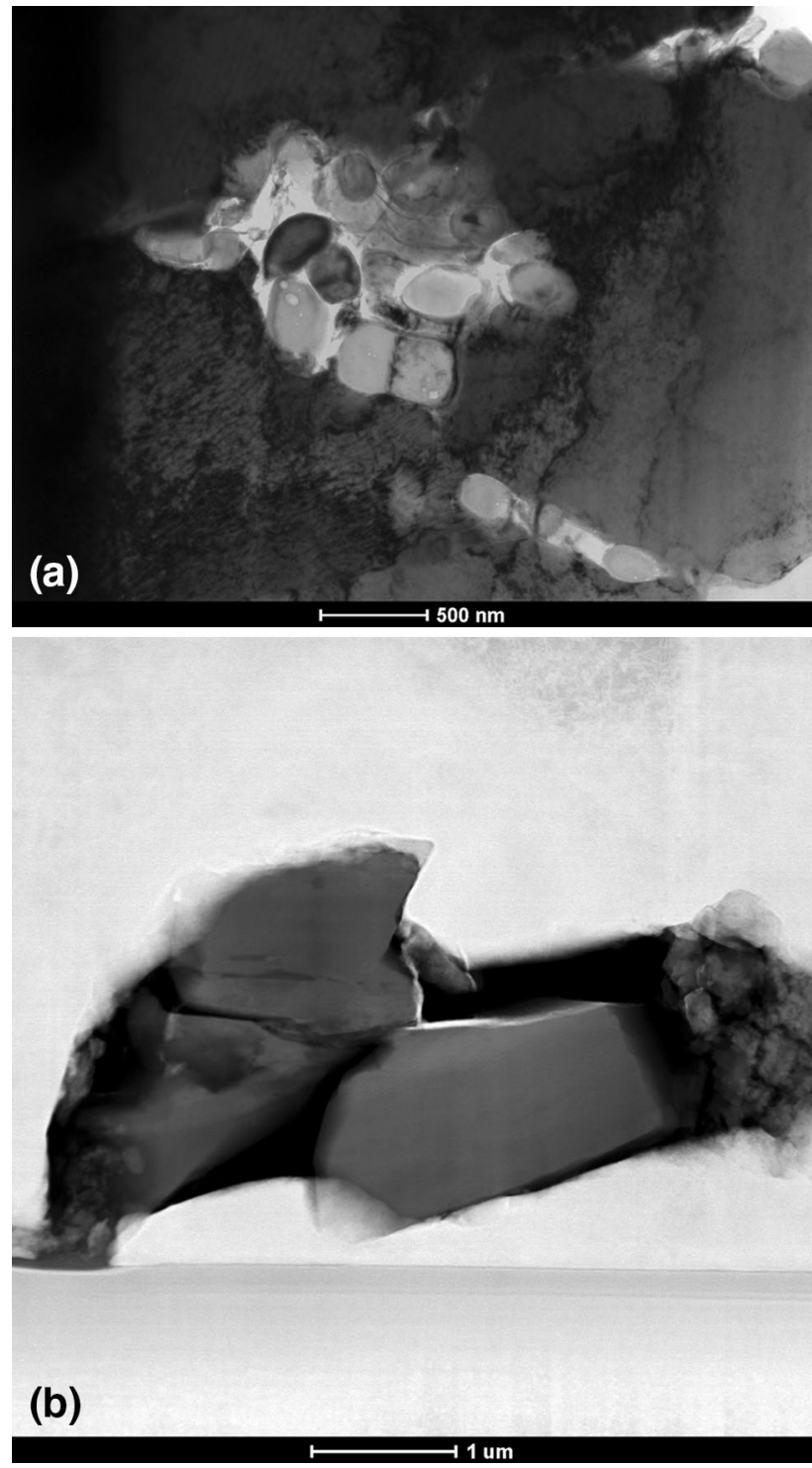

Fig. 8 TEM micrographs of composites: (a) $\mathrm{Cu}-5$ vol. $\% \alpha \mathrm{Al}_{2} \mathrm{O}_{3}$ (HP) and (b) $\mathrm{Cu}-5$ vol.\% ED $\mathrm{Al}_{2} \mathrm{O}_{3}$ (HP)

composite with the highest $\mathrm{Al}_{2} \mathrm{O}_{3}$ content, can be observed the presence of pores, mainly in the ceramic phase.

TEM microstructure investigation (Fig. 7) of the interface revealed a clean ceramic-metal boundary. There was no evidence of the presence of other phase. However, in the case of hot-pressed composites locally some amount of the $\mathrm{CuO}_{x}$ phase was observed.

Moreover, TEM investigation showed that $\alpha \mathrm{Al}_{2} \mathrm{O}_{3}$ powder grains are arranged in agglomerates (Fig. 8a), and there are empty spaces between grains forming these agglomerates. The performed research works indicate rather adhesive nature of the metal-ceramic bonding.

\subsection{Tribological Properties}

Looking from the point of view of prospective applications, the tribological properties of composites are particularly important. The coefficient of friction for both groups of composite materials is presented in Table 4. It can be stated that 
as a result of increasing hardness of materials, increasing content of the ceramic phase in a composite can, in consequence, increase friction coefficient. When it comes to composites containing $1 \%$ of the ceramic phase, behavior

Table 4 Volumes of the groove after resistance test for composites obtained by hot pressing method (HP)

Composite materials, vol. \%Friction coefficientVolume, $\times 10^{6} \mu^{3}$

\begin{tabular}{|c|c|c|}
\hline $\mathrm{Cu}$ & 0.30 & 8.10 \\
\hline $\mathrm{Cu}-1 \% \alpha \mathrm{Al}_{2} \mathrm{O}_{3}$ & 0.29 & 0.52 \\
\hline $\mathrm{Cu}-3 \% \propto \mathrm{Al}_{2} \mathrm{O}_{3}$ & 0.32 & 0.34 \\
\hline $\mathrm{Cu}-5 \% \propto \mathrm{Al}_{2} \mathrm{O}_{3}$ & 0.36 & 0.20 \\
\hline $\mathrm{Cu}-1 \% \mathrm{ED} \mathrm{Al}_{2} \mathrm{O}_{3}$ & 0.30 & 0.50 \\
\hline $\mathrm{Cu}-3 \% \mathrm{ED} \mathrm{Al}_{2} \mathrm{O}_{3}$ & 0.37 & 0.41 \\
\hline $\mathrm{Cu}-5 \% \mathrm{ED} \mathrm{Al}_{2} \mathrm{O}_{3}$ & 0.50 & 0.36 \\
\hline
\end{tabular}
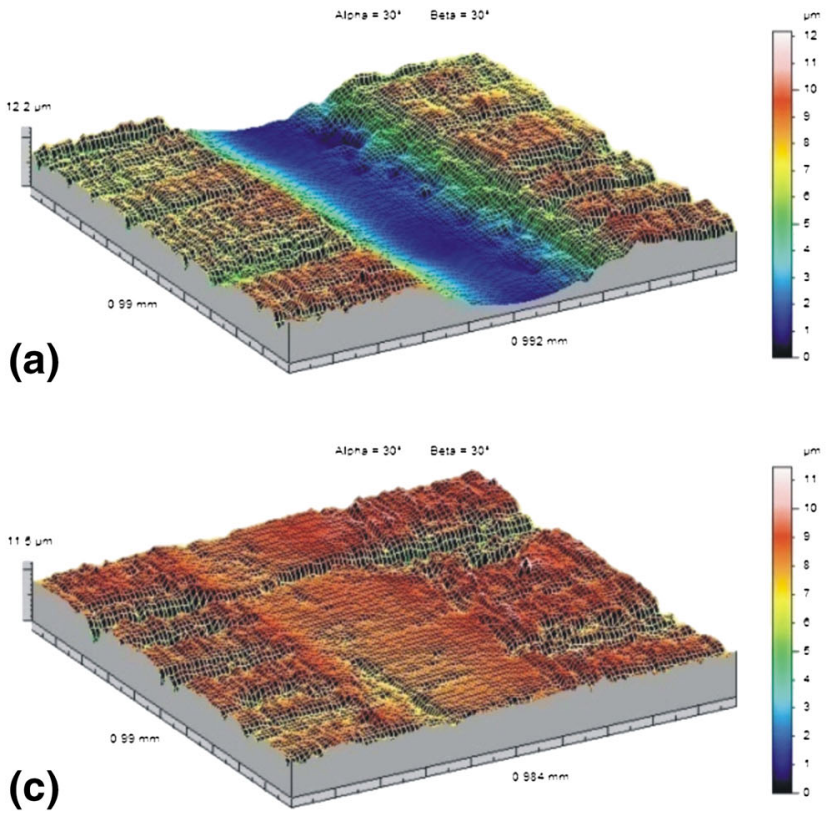

similar to that of pure copper, for which the coefficient of friction is around 0.3 , was recorded. The value of the coefficient of friction for $\mathrm{Cu}-\mathrm{ED} \mathrm{Al}_{2} \mathrm{O}_{3}$ composites is 0.37 (ceramic phase $3 \%$ vol.) and 0.50 (ceramic phase 5\% vol.). Changes in a temporary value of the coefficient of friction for friction pairs are $\Delta=\sim 0.1$ and stem from changeable resistance to motion during friction, resulting from numerous, minute gaps and transferred wear products (mass transfer). The main source of resistance to motion is plastic deformations and adhesion of the material of the sample to an abrasive ball. The material of the counterbody was not worn, and no traces of the removed composite material adhering to it were observed. Figure 9 shows the 3 -D profiles of the composite surface after the wear test. The increased content of ceramic phase results in an improved frictional wear resistance as shown in Table 4. The obtained values are an average of three measurements. In the case of materials with a higher content of $\mathrm{Al}_{2} \mathrm{O}_{3}$ (5 vol.\%), the counterbody slides on the surface of the composite, as a result of which wear of the surface is less prominent. For pure copper,

Fig. 9 Wear profiles after friction test for (a) copper (HP), b) $\mathrm{Cu}-1$ vol.\% $\alpha \mathrm{Al}_{2} \mathrm{O}_{3}(\mathrm{HP})$, (c) $\mathrm{Cu}-3$ vol.\% $\alpha \mathrm{Al}_{2} \mathrm{O}_{3}(\mathrm{HP}),(\mathrm{d}) \mathrm{Cu}-5$ vol.\% $\alpha \mathrm{Al}{ }_{2} \mathrm{O}_{3}$ (HP)
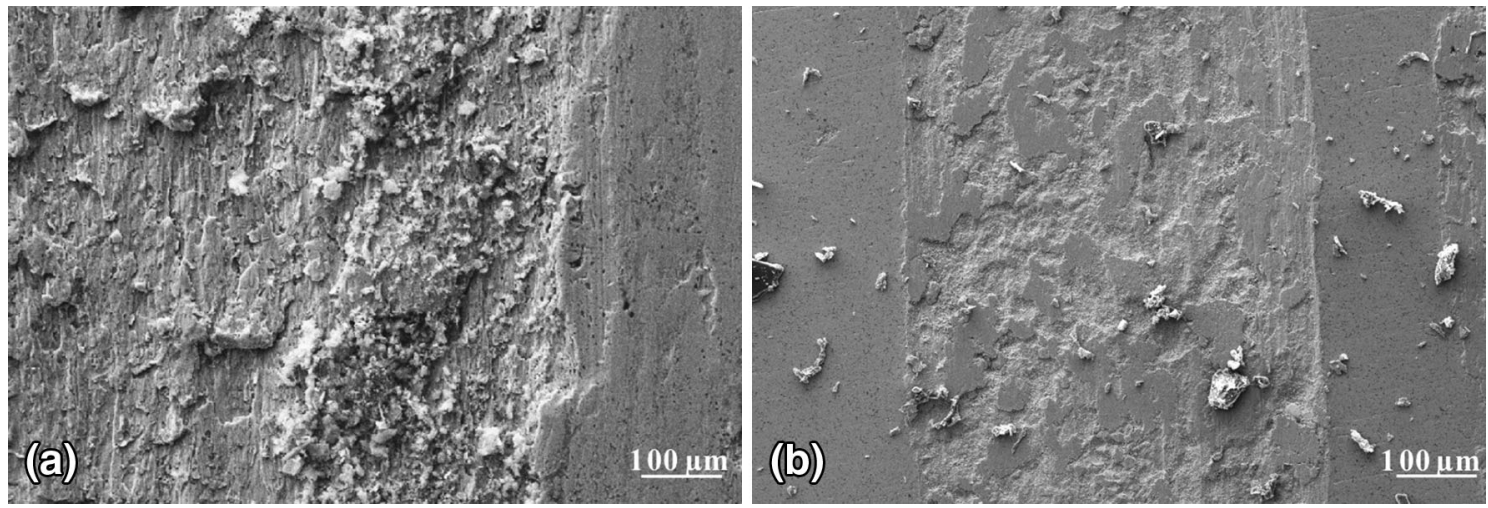

Fig. 10 SEM image of the groove area after friction test for (a) $\mathrm{Cu}-5$ vol. $\% \alpha \mathrm{Al}_{2} \mathrm{O}_{3}$ (HP) and (b) $\mathrm{Cu}-5$ vol. $\% \mathrm{ED} \mathrm{Al}_{2} \mathrm{O}_{3}(\mathrm{HP})$ 


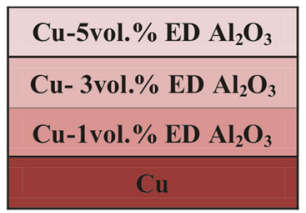

Fig. 11 Scheme of $\mathrm{Cu}-\mathrm{ED} \mathrm{Al}_{2} \mathrm{O}_{3}$ gradient material (FGM)

the wear pattern of its surface is plastic due to considerable hardness of the ball and composite material. Microscopic observations of grooves formed after friction tests were performed using a scanning electron microscope. The SEM images of $\mathrm{Cu}-5$ vol.\% $\alpha \mathrm{Al}_{2} \mathrm{O}_{3}$ and $\mathrm{Cu}-5$ vol.\% $\mathrm{ED} \mathrm{Al}_{2} \mathrm{O}_{3}$ composites are presented in Fig. 10.

It was found that for higher concentrations of ceramics, the width of wear traces is slightly lower and the surface is less defective. Based on the analysis of SEM images, it can be concluded that during the friction process, mainly wear products get agglomerated, creating a continuous tribo-layer on the surface of copper. Smoothing surface irregularities leads to the formation of local build-ups and gaps.

For $\mathrm{Cu}-\mathrm{ED} \mathrm{Al}_{2} \mathrm{O}_{3}$ composites, the surface of grooves is relatively smooth and one can notice slide lines, along which the counterbody moved. Single gaps and build-ups, leading to an intense friction process, are visible in the structure. In all analyzed instances for this group of materials, the presence of both fine ceramic and metallic particles removed during the friction process, which contribute to higher material wear than in the case of $\mathrm{Cu}-\alpha \mathrm{Al}_{2} \mathrm{O}_{3}$ composites, was confirmed.

\subsection{Microstructure Investigation of $\mathrm{Cu}-\mathrm{Al}_{2} \mathrm{O}_{3}$ Gradient Material}

The conducted investigation revealed that through a proper selection of the starting materials and the sintering technique of composite powders, one can achieve composite materials with target properties. The best physical, mechanical, and operational properties were obtained in the case of composited produced by spark plasma sintering (SPS) and those the reinforcing phase of which was in the form of electrocorundum. On this basis, a gradient material (FGM) was prepared. Its schematic diagram is shown in Fig. 11. The assumed thickness for the entire gradient material was $4 \mathrm{~mm}$ (i.e., $1 \mathrm{~mm}$ for each layer). Metallographic microsection was prepared from a cross section of the obtained gradient material, and afterward, it underwent examination using an optical microscope (Fig. 12).

The microstructural analysis of the outcome material with composition gradient did not show the presence of any structural defects for the areas at the boundary between individual layers of FGM. As the structural defects, we think about presence of discontinuities and microcracks, especially at the area close to the adjacent layers of FGM. It was observed some existing porosity within the individual layers. The pores were visible in different areas of FGM, exactly similar to the amount of porosity in each composites sintered separately. No discontinuities and delamination were observed on the boundary of the sintered layers, which proves that the sintering parameters were selected in a proper manner and stresses stemming from differences in the shrinkage of particular layers of the FGM do not cause any destruction in material structure.

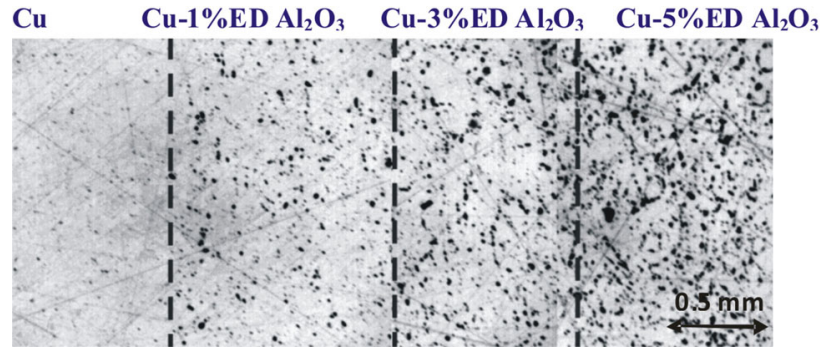

Fig. 12 Optical microscope image of sinter of Cu-fine-grained electrocorundum gradient material (FGM)

\section{Conclusions}

Based on the conducted research works it can be concluded that when changing the geometry and form of the ceramic phase in $\mathrm{Cu}-\mathrm{Al}_{2} \mathrm{O}_{3}$ composites and employing various manufacturing techniques of these materials, one is able to improve their properties, so crucial from the point of view of their future prospective applications. As a result of using electrocorundum in copper-based composites, it was possible to limit porosity in the ceramic phase, thus contributing to enhanced mechanical, thermal, and tribological properties of these composites. On the basis of the performed technological trials and research works, spark plasma sintering (SPS) was chosen, and electrocorundum was selected as the form of the reinforcing phase material used in the production of the material with composition gradient. The present experiment led to the production of a material with a known fraction of the ceramic phase $(1,3,5$ vol.\%) in the cross section. The investigation of the structure allowed us to conclude that the developed technology makes the production of the $\mathrm{Cu}-\mathrm{Al}_{2} \mathrm{O}_{3}$ gradient material with relative density and homogeneous distribution of the ceramic phase in the copper matrix (within the area of each layer) possible. No structure discontinuities were found between separate layers forming the gradient material which in the longer term is expected to be used as a component of thrusters.

\section{Acknowledgment}

The results presented in this paper have been obtained within the framework of the project funded by the Polish National Science Centre, decision number DEC-2014/13/N/ST8/00080 (PRELUDIUM) 2015-2017.

\section{Open Access}

This article is distributed under the terms of the Creative Commons Attribution 4.0 International License (http://creativecommons. org/licenses/by/4.0/), which permits unrestricted use, distribution, and reproduction in any medium, provided you give appropriate credit to the original author(s) and the source, provide a link to the Creative Commons license, and indicate if changes were made.

\section{References}

1. Ch Pelegris, N. Ferguen, W. Leclerc, Y. Lorgouilloux, S. Hocquet, O. Rigo, M. Guessasman, E. Bellenger, Ch Courtois, V. Lardot, and A. Leriche, Thermal Conductivity Modeling of Alumina/Al Functionally Graded Composites, Can. J. Chem. Eng., 2014, doi: $10.1002 /$ cjce. 22091 
2. J.J. Sobczak and L. Drenchev, Metallic Functionally Graded Materials: A Specific Class of Advanced Composites, J. Mater. Sci. Technol., 2013, 29(4), p 297-316

3. A.B. Sanuddin, A. Aidy, M. Azman, and M. Hanim, Fabrication of Al$\mathrm{Al}_{2} \mathrm{O}_{3}$ FGM Rotating Disc, Int. J. Automot. Mech. Eng., 2012, 5, p 622-629

4. K. Granat, K. Pietrzak, E. Grodzka, N. Naplocha, and J.W. Kaczmar, Production and Wear Properties of Copper Based MMC Strengthened with $\delta$-Alumina Fibers, Arch. Foundry Eng., 2011, 11, p 71-74

5. A. Fathy, F. Shehata, M. Abdelhameed, and M. Elmahdy, Compressive and Wear Resistance of Nanometric Alumina Reinforced Copper Matrix Composites, Mater. Design, 2012, 36, p 100-107

6. K.-M. Shu and G.C. Tu, The Microstructure and the Thermal Expansion Characteristics of $\mathrm{Cu} / \mathrm{SiC}$ Composites, Mater. Sci. Eng., 2003, A349, p 239-247

7. Y.M. Shabana, B.L. Karihaloo, H.X. Zhu, and S. Kulasagram, Influence of Processing Defects on the Measured Properties of $\mathrm{Cu}-\mathrm{Al}_{2} \mathrm{O}_{3}$ Composites: A Forensic Investigation, Compos. Part A, 2013, p 140-146

8. R. Jamaati and M.R. Toroghinejad, Application of ARB Process for Manufacturing High-Strength, Finely Dispersed and Highly Uniform $\mathrm{Cu} / \mathrm{Al}_{2} \mathrm{O}_{3}$ Composite, Mater. Sci. Eng. A, 2010, 527, p 7430-7435

9. D. Jarzabek, M. Chmielewski, and T. Wojciechowski, The Measurement of the Adhesion Force Between Ceramic Particles and Metal
Matrix in Ceramic Reinforced-Metal Matrix Composites, Compos. Part A, 2015, 76, p 124-130

10. J.S. Benjamin and T.E. Volin, The mechanism of mechanical alloying, Metall. Trans., 1974, p 1929-1934

11. M. Chmielewski, D. Kaliński, K. Pietrzak, and W. Włosiński, Relationship Between Mixing Conditions and Properties of Sintered 20AlN/80Cu Composite Materials, Arch. Metall. Mater., 2010, 55(2), p 579-587

12. A. Strojny-Nedza and K. Pietrzak, Processing, Microstructure and Properties of Different Method Obtained $\mathrm{Cu}-\mathrm{Al}_{2} \mathrm{O}_{3}$ Composites, Arch. Metall. Mater, 2014, 59(4), p 1301-1306

13. W. Wẹglewski, M. Basista, A. Manescu, M. Chmielewski, K. Pietrzak, and Th Schubert, Effect of Grain Size on Thermal Residual Stresses and Damage in Sintered Chromium-Alumina Composites: Measurement and Modeling, Compos. Part B, 2014, 67, p 119-124

14. M. Chmielewski, S. Nosewicz, K. Pietrzak, J. Rojek, A. StrojnyNedza, S. Mackiewicz, and J. Dutkiewicz, Sintering Behavior and Mechanical Properties of $\mathrm{NiAl}, \mathrm{Al}_{2} \mathrm{O}_{3}$ and $\mathrm{NiAl}-\mathrm{Al}_{2} \mathrm{O}_{3}$ Composites, $J$. Mater. Eng. Perform., 2014, 23(11), p 3875-3886

15. M. Chmielewski and W. Węglewski, Comparison of Experimental and Modeling Results of Thermal Properties in Cu-AlN Composite Materials, Bull. Pol. Acad. Sci, 2013, 61(2), p 507-514 